\title{
Nutrient and mineral assessment of edible wild fig and mulberry fruits
}

\author{
Haleema SAdia ${ }^{1}$, Mushtaq AHmad ${ }^{1,2}$, Shazia SultanA ${ }^{1,2 *}$, Ahmad Zuhairi Abdullah ${ }^{2}$, Lee KeAt Teong ${ }^{2}$, Muhammad ZAFAR $^{1}$, \\ Asghari BANO ${ }^{1}$
}

\author{
${ }^{1}$ Dep. Plant Sci., \\ Quaid-i-Azam Univ., \\ Islamabad, 45320, Pakistan, \\ shaziaflora@hotmail.com \\ 2 School Chem. Eng., \\ Univ. Saina Malaysia, 14300, \\ NibongTebal, Penang, \\ Malaysia
}

${ }^{*}$ Correspondence and reprints

Received 18 April 2013 Accepted 23 July 2013

Fruits, 2014, vol. 69, p. 159-166 (C) 2014 Cirad/EDP Sciences All rights reserved DOI: 10.1051/fruits/2014006 www.fruits-journal.org

RESUMEN EsPañol, p. 166

\begin{abstract}
Nutrient and mineral assessment of edible wild fig and mulberry fruits.
Abstract - Introduction. Edible wild plants are nature's gift to mankind. Considering the growing need to identify alternative bio-nutritional sources, some underutilized species of figs (Ficus carica L., F. palmata Forssk., F. racemosa L.) and mulberries (Morus alba L., M. nigra L, M. laevigata Wall.) of the family Moraceae were evaluated as wild edible fruits to study their nutritive and mineral composition in order to prioritize their edibility for indigenous people. Materials and methods. The major proximal components (moisture, ash, lipids, proteins, fibers and carbohydrates) were determined by standard AOAC methods. The concentration of various minerals (K, $\mathrm{Ca}, \mathrm{Mg}$ and $\mathrm{Na}$ ) and trace elements (Fe, $\mathrm{Mn}, \mathrm{Zn}, \mathrm{Cu}$ and $\mathrm{Ni}$ ) were recorded by using an atomic absorption spectrophotometer. Results. Our results indicated a range of moisture contents from $17.82-80.37 \mathrm{~g} \cdot 100 \mathrm{~g}^{-1}$ (fresh weight basis) in F. carica-M. laviegata; protein, 6.31-13.50 g.100 g-1 (dry weight basis) in F. glomerata-M. alba; crude fats, $1.02-2.71 \mathrm{~g} \cdot 100 \mathrm{~g}^{-1}$ in F. palmate-F. glomerata; carbohydrates $69.47-75.58 \mathrm{~g} \cdot 100 \mathrm{~g}^{-1}$ in M. alba-M. nigra; and fiber 7.63-17.81 g.100 g-1 in $M$. laviegata-F. palmate, respectively. The significantly highest energy value was computed in M. laviegata $\left(367.7 \mathrm{kcal} \cdot 100 \mathrm{~g}^{-1}\right)$. Moreover, sufficient quantities of essential elements were found in all the studied materials. The highest levels of $N^{2}\left[(0.24 \pm 0.07) \mathrm{mg}^{-1} \mathrm{~g}^{-1}\right]$ and Fe $[(1.43 \pm$ $\left.0.42 \mathrm{mg} \cdot \mathrm{g}^{-1}\right]$ were found in M. laviegata; $\mathrm{Na}\left[\left(1.92 \pm 0.11 \mathrm{mg} \cdot \mathrm{g}^{-1}\right]\right.$ and $\mathrm{Mg}\left[\left(6.92 \pm 0.37 \mathrm{mg} \cdot \mathrm{g}^{-1}\right]\right.$ in F. palmate; and $\mathrm{K}\left[\left(17.21 \pm 0.03 \mathrm{mg} \cdot \mathrm{g}^{-1}\right]\right.$ in $F$. glomerata. Significant variation existed among the selected species in all the nutritional parameters. Conclusion. According to our results, fig and mulberry fruits are recommended for commercial-scale production for the green industry to overcome food crises as they are potential food sources, particularly Morus laviegata and Ficus palmata, with rich nutritional attributes and mineral profiles.
\end{abstract}

Pakistan / Morus / Ficus / fruits / proximate composition / mineral content

\section{Évaluation des nutriments et des ressources minérales des fruits de figuiers} et de mûriers sauvages comestibles.

Résumé - Introduction. Les plantes sauvages comestibles sont un don que fait la nature à l'humanité. Considérant le besoin croissant d'identifier de nouvelles sources de bio-nutrition, certaines espèces sous-utilisées de figuiers (Ficus carica L., F. palmata Forssk., F. racemosa L.) et de mûriers (Morus alba L., M. nigra L, M. laevigata Wall.) de la famille des Moraceae ont été évaluées en tant que fruits sauvages comestibles pour étudier leur composition nutritive et minérale afin de prioriser leur consommation auprès des populations autochtones. Matériel et méthodes. La composition globale des fruits étudiés (humidité, cendres, lipides, protéines, fibres et glucides) a été déterminée par utilisation de méthodes AOAC standards. La concentration en divers minéraux $(\mathrm{K}, \mathrm{Ca}, \mathrm{Mg}$ et $\mathrm{Na})$ et en oligo-éléments $(\mathrm{Fe}, \mathrm{Mn}, \mathrm{Zn}, \mathrm{Cu}$ et $\mathrm{Ni})$ a été déterminée en utilisant un spectrophotomètre d'absorption atomique. Résultats. Nos résultats ont révélé une gamme de teneurs en humidité de $17,82-80,37 \mathrm{~g} \cdot 100 \mathrm{~g}^{-1}$ (poids frais) pour $F$. carica-M. laviegata; en protéines, de $6,31-13,50 \mathrm{~g} \cdot 100 \mathrm{~g}^{-1}$ (poids sec) pour $F$. glomerata- $M$. alba ; en graisses brutes, de 1,02 $2,71 \mathrm{~g} \cdot 100 \mathrm{~g}^{-1}$ pour F. palmate-F. glomerata; en glucides, de $69,47-75,58 \mathrm{~g} \cdot 100 \mathrm{~g}^{-1}$ pour M. alba$M$. nigra ; en fibres, de 7,63-17,81 g.100 $\mathrm{g}^{-1}$ pour M. laviegata-F. palmate, respectivement. Une valeur énergétique significativement élevée a été calculée pour $M$. laviegata $\left(367,7 \mathrm{kcal} \cdot 100 \mathrm{~g}^{-1}\right)$. En outre, des quantités non négligeables d'éléments essentiels ont été trouvées chez toutes les espèces étudiées. Les plus hauts niveaux de $\mathrm{N}\left[(0,24 \pm 0,07) \mathrm{mg} \cdot \mathrm{g}^{-1}\right]$ et Fe $\left[\left(1,43 \pm 0,42 \mathrm{mg} \cdot \mathrm{g}^{-1}\right]\right.$ ont été trouvés dans $M$. laviegata; de Na $\left[\left(1,92 \pm 0,11 \mathrm{mg} \cdot \mathrm{g}^{-1}\right]\right.$ et $\mathrm{Mg}\left[\left(6,92 \pm 0,37 \mathrm{mg} \cdot \mathrm{g}^{-1}\right]\right.$, dans $F$. palmate ; et K $\left[\left(17,21 \pm 0,03 \mathrm{mg} \cdot \mathrm{g}^{-1}\right]\right.$, dans $F$. glomerata. Des variations significatives sont apparues entre les espèces étudiées pour tous les éléments nutritionnels. Conclusion. Selon nos résultats, les fruits de figuiers et de mûriers devraient être recommandés à l'échelle d'une production commerciale pour l'industrie verte afin de surmonter les crises alimentaires en tant que source potentielle en alimentation quotidienne, particulièrement les fruits de Morus laviegata et Ficuspalmata qui ont de riches propriétés nutritionnelles et profils minéraux.

Pakistan / Morus / Ficus / fruits / composition globale / teneur en éléments minéraux 


\section{Introduction}

In recent years, wild food plants have become very attractive to the food industry, prompting their use as replacements for synthetic chemicals and nutraceuticals. Food plants are an integral part of the subsistence strategy of rural people in many developing countries and they play a key role in preventing many diseases. In particular, the wild edibles with proven nutritional and pharmaceutical potential have emerged as potential resources for addressing issues of side effects of synthetic chemical-based food ingredients in many regions [1, 2]. Among the green natural edibles, some species of the genus Ficus (F. carica, F. racemosa, F. palmate: common figs) and Morus (M. alba, M. nigra, M. laviegata: common mulberries) are consumed widely by the tribal communities of the Himalayan range, significantly for their nutritional security. However, such neglected and underutilized natural food resources are suffering from less attention and research, and their nutritional, economic and socio-cultural potential are not fully exploited.

Figs and mulberries are perennial woody trees that belong to the family Moraceae. They can grow in a wide range of climatic and topographical conditions, viz., tropical, subtropical and temperate parts of the world. Some species (M. alba, M. nigra, $F$. racemosa) are preferred due to their foliage yield and delicious fruits, while others (F. carica and M. laviegata) have strong environmental adaptability. These fruits can be eaten fresh or dried and also be processed into juices, paste or pulp [3, 4]. A number of detailed studies show the health benefits of these medicinal fruits as they have considerable antimicrobial, antifungal, anti-allergic, antioxidant and antihypoglycemic activities. Kostic et al. reported the high phenolic content and antioxidant activity of black and white mulberries grown in Serbia, showing the nutritive and medicinal potential of the fruits [5]. The leaves, bark and branches of white and black mulberries have long been used in traditional Chinese medicine for the treatment of arthritis, diabetes and rheumatism [6-8]. Wild figs (F. carica and F. palmata) are rich in minerals and sugars, predominantly fructose and glucose. Their fruits are known to be a rich source of minerals, phenolics, anthocyanins and flavonoids [9, 10]. The chemical composition and nutritional status of plant edibles may be influenced by the physiological and environmental factors of the area, such as soil chemistry and climatic conditions [11].

Among the known edible fruits of Moraceae, only a few have been analyzed for their mineral contents (Morus alba, Morus nigra) $[12,13]$. However, in previous studies there was no conclusive and comprehensive investigation reported on the nutritional composition of Ficus carica L., F. palmate Forssk., F. racemosa L., Morus alba L., M. nigra L. and M. laevigata Wall. Our study presents a comparative account of macro- and micronutrients in green fruits that will probably be used in the future in the green industry for healthy food on a commercial scale.

\section{Materials and methods}

\subsection{Materials}

Fresh fully ripened fruits of three seasons (2011-2012) were collected from different localities of the lesser Himalayan region of Pakistan in order to make composite samples. Their botanical identification was confirmed with specimens in the Herbarium of Pakistan (ISL) Qauid-i-Azam University, Islamabad. Samples were oven-dried at $68^{\circ} \mathrm{C}$ for $24 \mathrm{~h}$ and ground into fine powder for nutritional analysis. All chemicals used in this study were of analytical grade and purchased from Merck Chemicals (Germany).

\subsection{Proximate analysis}

The standard methods [14] were adopted to determine the proximate composition of fruit samples; moisture [weighing the fresh samples before and after oven drying at $(103 \pm 2)^{\circ} \mathrm{C}$ for $24 \mathrm{~h}$ ], nitrogen (microKjeldahl-UDK-127, VELP Scientifica, Italy), 
crude protein (calculated as $N \times 6.25$ ), ash (incineration in a muffle furnace at $550{ }^{\circ} \mathrm{C}$ ), crude fat (solvent extraction in a Soxhlet apparatus using petroleum ether with a boiling point range of $60-90{ }^{\circ} \mathrm{C}$ ), crude fiber (extraction with $1.25 \% \mathrm{NaOH}$, drying the residue for $4 \mathrm{~h}$ at $102{ }^{\circ} \mathrm{C}$ followed by muffle incineration at $600{ }^{\circ} \mathrm{C}$ for $30 \mathrm{~min}$ ) [15, 16], total carbohydrates [17] and gross food energy $[4 \times$ protein, $4 \times$ carbohydrate, $9 \times$ fat) $\left.\mathrm{kcal} \cdot 100 \mathrm{~g}^{-1}\right][18,19]$.

\subsection{Mineral assessment}

The acid digestion methods of Toth et al. [20] and Hussain and Khan [21] with some modifications were followed to determine inorganic constituents. Each sample (0.2 g) was digested with a mixture of $\mathrm{HNO}_{3}$ and $\mathrm{HClO}_{4}(4: 1, \mathrm{v} / \mathrm{v})$ at room temperature overnight and heated at $130{ }^{\circ} \mathrm{C}$ for $1 \mathrm{~h}$ until a clear solution was obtained (about $2 \mathrm{~mL}$ ). The solution was subsequently transferred to a 25-mL volumetric flask and diluted with ultrapure water after cooling. A blank digest was carried out in the same way. The amount of inorganic elements, viz., Na, K, $\mathrm{Ca}, \mathrm{Mg}, \mathrm{K}, \mathrm{Fe}, \mathrm{Mn}, \mathrm{Zn}, \mathrm{Pb}, \mathrm{Ni}, \mathrm{Co}, \mathrm{Cd}$ and $\mathrm{Cu}$, were estimated by using an Atomic Absorption Spectrophotometer (Perkin Elmer, AA Analyst 200, USA). Phosphorus was estimated from the same acid digest by following the method described by Sekine et al. [22].

\subsection{Statistical analysis}

Descriptive statistics were performed by using Microsoft Excel 2007 to calculate mean and standard errors for nutritional contents of fruit samples.

\section{Results and discussion}

\subsection{Nutritional properties}

The data on proximate composition of nutrients in fig and mulberry fruits show that mulberries contain higher moisture content $\left[(80.37 \pm 0.14) \mathrm{g} \cdot 100 \mathrm{~g}^{-1}\right.$ fresh weight in $M$. laviegata) than figs [(17.82 \pm $0.21) \mathrm{g} \cdot 100 \mathrm{~g}^{-1}$ fresh weight in F. carica] (table I). The moisture content is one of the important factors as many of the physical properties of edible fruits may vary due to changing its value [23]. The percentage of moisture in mulberries [ $80.37 \pm$ 0.14) $\mathrm{g} \cdot 100 \mathrm{~g}^{-1}$ fresh weight in M. laviegata] was similar to that in most of the conventional fruits (about 75-95\%), while it was lower in figs [(17.82 \pm 0.21$) \mathrm{g} \cdot 100 \mathrm{~g}^{-1}$ fresh weight in F. carical as compared with other wild berries such as strawberry (56\%) [24].

The highest quantity of lipid and protein was found in $F$.glomerata $[(2.71 \pm$ $0.03) \mathrm{g} \cdot 100 \mathrm{~g}^{-1}$ dry weight] and $M$. alba $\left[(13.50 \pm 0.28) \mathrm{g} \cdot 100 \mathrm{~g}^{-1}\right.$ dry weight], respectively (table I). Nutritionally, fat is the less abundant macronutrient, being lower than $2 \%$, and the protein level is usually $5 \%$ or above and varies in different fruits $[25,26]$. The figs and mulberries contain a higher protein quantity $[M$. alba: $(13.50 \pm 0.28) \mathrm{g} \cdot 100 \mathrm{~g}^{-1}$ dry weight and $F$. carica: $(8.60 \pm 0.96) \mathrm{g} \cdot 100 \mathrm{~g}^{-1}$ dry weight] than the edible part of sunberry (2.7\%) and Dabai fruit (3.8\%) [27, 28]. Ficus palmata could be a good source of fibers, with exceptionally high crude fiber content [(17.81 \pm 0.03$) \mathrm{g} \cdot 100 \mathrm{~g}^{-1}$ dry weight $]$ among all the studied fruits (table I). Morus species also have a considerable content of dietary fiber [M. alba: $(11.0 \pm 0.75) \mathrm{g} \cdot 100 \mathrm{~g}^{-1}$ dry weight], which is higher than that of other fruits such as Indian Dabai fruit (4.3\%) [28]. The carbohydrates were found to be the most abundant macronutrient: (75.58 \pm $0.54) \mathrm{g} \cdot 100 \mathrm{~g}^{-1}$ dry weight in M. nigra (table I). The content of total available carbohydrates in mulberries and figs was three-fold that in other wild fruits, viz., strawberry (23.55\%), dabai (22.1\%), etc., resulting in their high caloric value [24, 28]. Other authors reported that wild edible fruits have a good composition of different carbohydrates, either monosaccharides or polysaccharides, making them very nutritious for health products [24].

Fig and mulberry fruits show reasonably high food energy values due to higher carbohydrate content. The highest value of food energy was reported in Morus laviegata 


\begin{tabular}{|c|c|c|c|c|c|c|c|c|}
\hline \multirow{2}{*}{ Fruit species studied } & & \multirow{2}{*}{$\begin{array}{c}\text { Moisture } \\
\left(\mathrm{g} \cdot 100 \mathrm{~g}^{-1}\right. \\
\text { fresh weight) }\end{array}$} & Ash & Fats & Fiber & Protein & Carbohydrates & \multirow{2}{*}{$\begin{array}{c}\text { Energy } \\
\text { (kcal. } 100 \mathrm{~g}^{-1} \\
\text { dry weight) }\end{array}$} \\
\hline & & & \multicolumn{5}{|c|}{ (g.100 $\mathrm{g}^{-1}$ dry weight) } & \\
\hline \multirow[t]{3}{*}{ Mulberries (Morus spp.) } & M. alba & $80.24 \pm 0.15$ & $4.55 \pm 0.09$ & $1.48 \pm 0.84$ & $11.0 \pm 0.75$ & $13.50 \pm 0.28$ & $69.47 \pm 0.69$ & $345.4 \pm 0.49$ \\
\hline & M. nigra & $80.14 \pm 0.05$ & $3.92 \pm 0.01$ & $1.93 \pm 0.06$ & $8.23 \pm 0.07$ & $10.34 \pm 0.04$ & $75.58 \pm 0.54$ & $361.1 \pm 0.98$ \\
\hline & M. laviegata & $80.37 \pm 0.14$ & $3.46 \pm 0.11$ & $2.42 \pm 0.32$ & $7.63 \pm 0.33$ & $12.41 \pm 0.05$ & $74.09 \pm 0.22$ & $367.7 \pm 0.35$ \\
\hline \multirow[t]{3}{*}{ Figs (Ficus spp.) } & F. carica & $17.82 \pm 0.21$ & $4.50 \pm 0.41$ & $1.50 \pm 1.32$ & $14.20 \pm 0.38$ & $8.60 \pm 0.96$ & $71.20 \pm 0.29$ & $332.7 \pm 0.74$ \\
\hline & F. glomerata & $21.17 \pm 0.03$ & $3.90 \pm 0.04$ & $2.71 \pm 0.03$ & $16.80 \pm 0.12$ & $6.31 \pm 0.08$ & $70.31 \pm 0.41$ & $330.4 \pm 0.74$ \\
\hline & F. palmata & $19.42 \pm 0.16$ & $4.31 \pm 0.12$ & $1.02 \pm 0.19$ & $17.81 \pm 0.03$ & $6.50 \pm 0.18$ & $70.40 \pm 0.18$ & $316.8 \pm 0.82$ \\
\hline
\end{tabular}

$\left[(367.74 \pm 0.35) \mathrm{kcal} \cdot 100 \mathrm{~g}^{-1}\right.$ dry weight $]$ (table I). The energy values of edible figs and mulberries were comparable with different species of Grewia and Cordia, while they were higher than species of Berberis (83.9 kcal.100 $\mathrm{g}^{-1}$ dry weight) $[29,30]$.

In our findings, the proximal profile of these fruits is in accordance with standard values for the same species (M. alba, M. nigra) of South Asian and Turkish origin [31]. Little variations in the quantity of moisture, protein, fiber, oil and ash contents from previous reports are probably due to different environmental conditions and analytical methods. The results show that the consumption of these fruits as snacks was appropriate for the particular purpose of satisfying hunger in view of their carbohydrate content and caloric potential. These wild fruit species are recommended as an important nutritious source in the daily diet of locals specifically during famine periods, as the results showed 45-55 mulberries (100 g) provide $345.4-367.74 \mathrm{kcal}$ and 30-35 figs (100 g) produce $316.8-332.7 \mathrm{kcal}$.

\subsection{Mineral composition}

The essential minerals are important components of the daily diet required in greater quantity and represent $1 \%$ or less of body weight [32]. The results regarding the mineral and trace element levels in the figs and mulberries studied show that potassium has the highest concentration: (16.73 \pm $0.37)^{~ m g \cdot g^{-1}}$ dry weight in Morus alba and
$(17.21 \pm 0.03) \mathrm{mg} \cdot \mathrm{g}^{-1}$ dry weight in Ficus glomerata (table II). These results show higher $\mathrm{K}$ levels for M. alba and M. nigra than those of Ercisli and Orhan [10] for the same species of Mediterranean origin [(1.66-9.22) $\mathrm{mg} \cdot \mathrm{g}^{-1}$ in M. alba-M. nigra]. Potassium is one of the important nutrients for controlling human blood pressure, therefore fig and mulberry fruits were recommended for hypertension in previous studies.

Similarly, calcium is a major component of bone and assists in tooth development [33]. In our findings, the highest $\mathrm{Ca}$ was reported in Ficus carica [(10.94 \pm $2.75) \mathrm{mg} \cdot \mathrm{g}^{-1}$ dry weight] and the lowest in

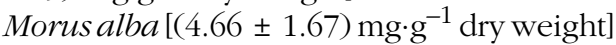
(table II). The recommended daily calcium intake for adults ranges from $1000 \mathrm{mg}$ to $1500 \mathrm{mg}$. It is also recommended to take supplements with food to aid in absorption. Compared with other metals, the calcium ion and most of its compounds have low toxicity [34].

The quantity of magnesium, sodium and phosphorus varies: $(2.02 \pm 1.42)$ to $(6.92 \pm$ $0.37) \mathrm{mg} \cdot \mathrm{g}^{-1}$ dry weight in $F$. carica $-F$. palmata, $(0.19 \pm 0.02) \mathrm{mg}^{-1}$ to $(1.92 \pm$ $0.11) \mathrm{mg} \cdot \mathrm{g}^{-1}$ dry weight in $M$. alba $-F$. palmata and $(0.12 \pm 0.09) \mathrm{mg} \cdot \mathrm{g}^{-1}$ to $(1.50 \pm$ $0.93) \mathrm{mg}^{-1}$ dry weight in $M$. alba $-F$. glomerata, respectively. It is indicated that fig and mulberry fruits constitute a relatively higher amount of minerals than fruits such as mango [calcium $(0.169 \pm 2.0) \mathrm{mg} \cdot \mathrm{g}^{-1}$, magnesium $(0.067 \pm 1.0) \mathrm{mg}^{-1} \mathrm{~g}^{-1}$, potassium 


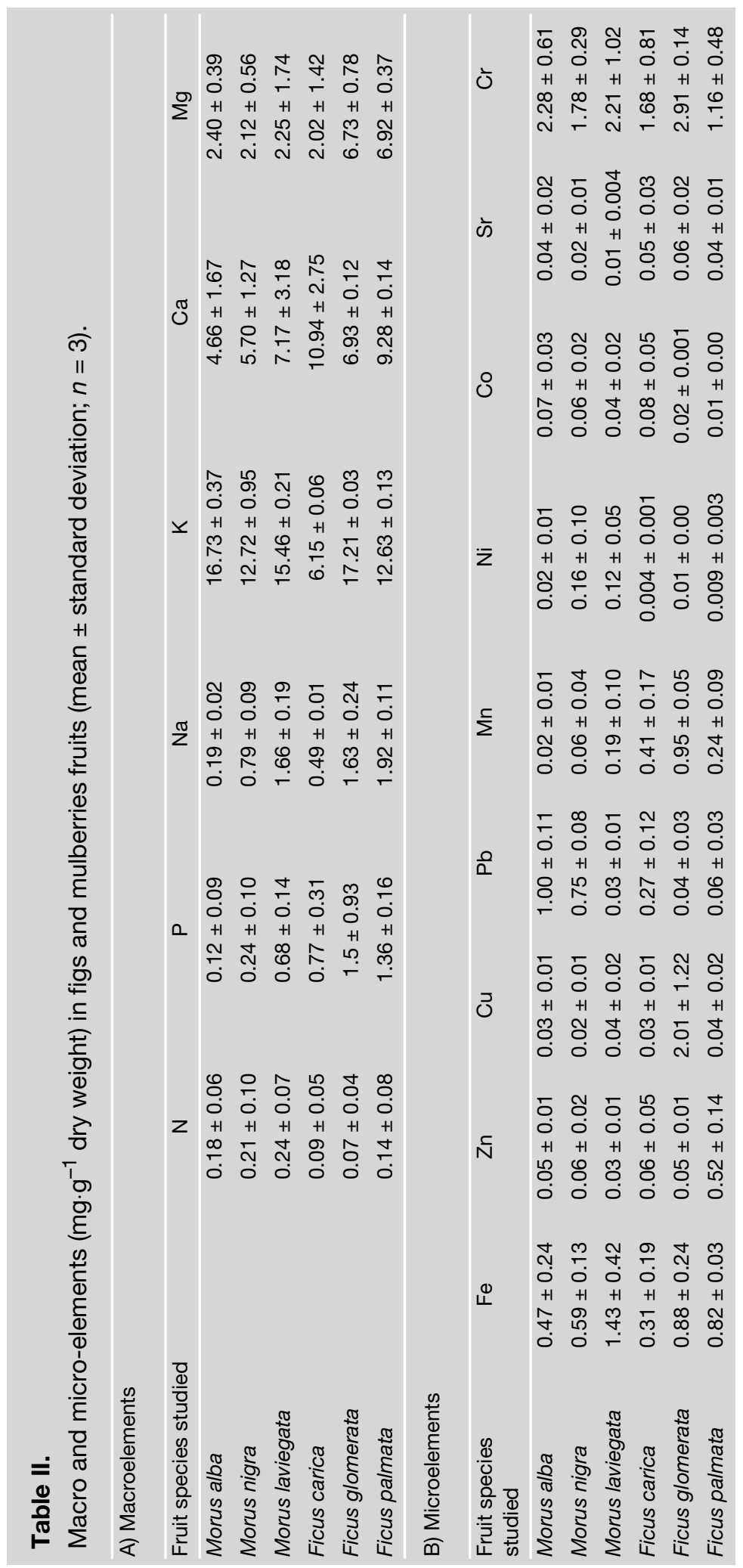


$(0.98 \pm 1.0) \mathrm{mg} \cdot \mathrm{g}^{-1}$, phosphorous $(0.07 \pm$ $0.8) \mathrm{mg}^{-1} \mathrm{~g}^{-1}$. These minerals also act as COfactors for many enzymes in the human body [35].

Trace minerals (Fe, $\mathrm{Zn}, \mathrm{Cu}, \mathrm{Pb}, \mathrm{Mn}, \mathrm{Ni}$, $\mathrm{Co}, \mathrm{Sr}$ and $\mathrm{Cr}$ ) are required in smaller amount but are essential as their excess or lack may be harmful for the body.

Iron $(\mathrm{Fe})$ content was highest [(1.43 \pm $0.42)^{~} \mathrm{mg}^{-1} \mathrm{~g}^{-1}$ dry weight] in Morus laviegata and lowest in Ficus carica $[(0.31 \pm$ 0.19 ) $\mathrm{mg} \cdot \mathrm{g}^{-1}$ ) (table II). An adequate level of $\mathrm{Fe}$ is required for hemoglobin formation in blood, while excessive intake can result in hemochromatosis. Iron-containing enzymes and proteins participate in many biological oxidations and in transport [36]. The copper, zinc and manganese content of the figs and mulberries varied from $(0.02 \pm$ $0.01) \mathrm{mg} \cdot \mathrm{g}^{-1}$ to $(2.01 \pm 1.22) \mathrm{mg} \cdot \mathrm{g}^{-1},(0.03 \pm$ $0.01) \mathrm{mg} \cdot \mathrm{g}^{-1}$ to $(0.52 \pm 0.14) \mathrm{mg} \cdot \mathrm{g}^{-1}$ and $(0.02 \pm 0.01) \mathrm{mg} \cdot \mathrm{g}^{-1}$ to $(0.95 \pm 0.05) \mathrm{mg} \cdot \mathrm{g}^{-1}$, respectively (table II). It is reported that a deficiency of $\mathrm{Mn}, \mathrm{Zn}$ and $\mathrm{Cu}$ may lead to bone deformities, reduced hair growth and cardiac abnormalities [37]. The present contents of $\mathrm{K}, \mathrm{Ca}, \mathrm{Mg}, \mathrm{Fe}$ and $\mathrm{Cu}$ in white [(16.73 \pm 0.37$),(4.66 \pm 1.67),(2.40 \pm 0.39)$, $(0.47 \pm 0.24)$ and $(0.03 \pm 0.01)] \mathrm{mg} \cdot \mathrm{g}^{-1}$ and black $[(12.72 \pm 0.95),(5.70 \pm 1.27),(2.12 \pm$ $0.56),(0.59 \pm 0.13)$ and $(0.02 \pm 0.01)] \mathrm{mg} \cdot \mathrm{g}^{-1}$ mulberries were high with respect to the results of Ercisli and Orhan [10]. Indeed, the authors reported, for $M$. alba and M. nigra, $\mathrm{K}$ : (1.66 and 9.22) $\mathrm{mg}^{-1} \mathrm{~g}^{-1}$, Ca: (1.55 and 1.32) $\mathrm{mg} \cdot \mathrm{g}^{-1}, \mathrm{Mg}: 1.06 \mathrm{mg} \cdot \mathrm{g}^{-1}$ in both, Fe: $0.04 \mathrm{mg} \cdot \mathrm{g}^{-1}$ in both species, and $\mathrm{Cu}$ : $(0.005$ and 0.004$) \mathrm{mg} \cdot \mathrm{g}^{-1}$. Our results regarding the content of Mn were $(0.02 \pm 0.01) \mathrm{mg} \cdot \mathrm{g}^{-1}$ for M. alba and $(0.06 \pm 0.04) \mathrm{mg} \cdot \mathrm{g}^{-1}$ for $M . n i$ gra. Contents of $\mathrm{Zn}$ for $M$. alba were $(0.05 \pm$ $0.01) \mathrm{mg} \cdot \mathrm{g}^{-1}$ and $(0.06 \pm 0.02) \mathrm{mg}^{-1} \mathrm{~g}^{-1}$ for $M$. nigra. These contents were comparable with pre-existing reports [for $M$. alba and M. nigra, Mn: (0.03 and 0.04) $\mathrm{mg}^{-\mathrm{g}^{-1}}, \mathrm{Zn}$ : $(0.02$ and 0.03$\left.) \mathrm{mg} \cdot \mathrm{g}^{-1}\right]$. These variations might be due to growth conditions and geographical variations. Our study reports a similar concentration of $\mathrm{Cr}$ in Ficus glomerata $\left[(27.68 \pm 2.81) \mathrm{mg} \cdot \mathrm{g}^{-1}\right]$ to that in a previous investigation $\left(27.07 \mathrm{mg} \cdot \mathrm{g}^{-1}\right)$ [38]; $\mathrm{Cr}$ is very useful in improving heart function, and balancing blood sugar and cholesterol levels [39].

According to our results, the wild mulberries and figs studied contain higher concentrations of trace elements as compared with cultivated fruits such as orange, grapes and apple $\left[(1.31 \pm 0.4) \mathrm{mg} \cdot 100 \mathrm{~g}^{-1}\right.$ of $\mathrm{Fe}, \quad(0.17 \pm 0.2) \mathrm{mg} \cdot 100 \mathrm{~g}^{-1}$ of $\mathrm{Cu}$, $(0.54 \pm 0.12) \mathrm{mg} \cdot 100 \mathrm{~g}^{-1}$ of $\mathrm{Zn}$, and $(0.58 \pm$ $0.10) \mathrm{mg} \cdot 100 \mathrm{~g}^{-1}$ of $\mathrm{Mn}$. The daily trace mineral requirements of an adult man range from: $10-15 \mathrm{mg} \mathrm{Fe}, 12-15 \mathrm{mg} \mathrm{Zn}$ and 2-3 mg Cu [40]. In our study, Morus laviegata and Ficus palmata possess superior nutritional status in terms of macroand micronutrients.

\section{Conclusions}

Six wildly grown fruits of figs and mulberries were studied for nutritional and mineral composition by following standard proximate analyses. Our findings show that figs and mulberries are promising sources of protein, carbohydrate, fibers and vitamins, with high energy values and essential micronutrients such as $\mathrm{K}, \mathrm{Mg}, \mathrm{Ca}, \mathrm{P}$ and Fe. Further research should therefore be conducted on fruits such as figs and mulberries and the results of such studies should be disseminated to the public. This will ensure dietary diversity and food security in different parts of the world.

\section{Acknowledgments}

The authors are grateful for the financial support provided by the Higher Education Commission of Pakistan (HEC), TWAS and IPS-Universiti Saina Malaysia for conducting this project.

\section{References}

[1] Sozzi G.O., Abrajan-Villasenor M.A., Trinchero G.D., Fraschina A.A., Postharvest response of Brown Turkey figs (Ficus carica L.) to the inhibition of ethylene perception, J. Sci. Food Agric. 85 (2005) 2503-2508. 
[2] Masi L.D., Castaldo D., Galan G., Minasi P., Laratta B., Genotyping of fig (Ficus carica L) via RAPD markers, J. Sci. Food Agric. 85 (2005) 2235-2242.

[3] Maskan M., Gogus F., Sorption isotherm and drying characteristics of mulberry (Morus alba), J. Food Eng. 37 (1998) 437-449.

[4] Khan M.N., Sarwar A., Adeel M., Wahab M.F., Nutritional evaluation of Ficus carica indigenous to Pakistan, Afr. J. Agric. Nutr. Dev. 11 (2011) 5187-5190.

[5] Kostic D.A., Dimitrijevic D.S., Stojanovic G.S., Mitic S.S., Mitic M.N., Phenolic composition and antioxidant activity of fresh fruit extracts of mulberries from Serbia, Oxid. Commun. (2013) 36 (1) 4-14.

[6] Lee E.J., Chae O.H., Lee M.S., Lee H.K., Huh $\mathrm{H}$., Purification of anti-allergic compound from mori cortex radicis extract, Yakhak Hoechi. 42 (1998) 395-402.

[7] Hikino H., Mozuno T., Oshima Y., Konno C., Validity of the oriental medicines, antidiabetics drugs, Isolation and hypoglycemic activity of moran A, a glycoprotein of Morus alba root barks, Planta Med. 2 (1985) 159-160.

[8] Kim S.Y., Gao J.J., Lee W.C., Ryu K.S., Lee K.R., Kim Y.C., Antioxidative flavonoids from the leaves of Morus alba, Arch. Pharm. Res. 22 (1995) 81-85.

[9] Kusano G., Orihara S., Tsukamoto D., Shibano M., Coskun M., Guvenc A., Erdurak C.S., Five new nortropanen alkaloids and six new amino acids from the fruit of Morus alba L. growing in Turkey, Chem. Pharm. Bull. 50 (2002) 185192.

[10] Ercisli S., Orhan E., Chemical composition of white (Morus alba), red (Morus rubra) and black ( $M$. nigra) mulberry fruits, Food Chem. 103 (2007) 1380-1384.

[11] Gungor N., Sengul M., Antioxidant activity, total phenolic content and selected physicochemical properties of white mulberry (Morus alba L.) fruits, Int. J. Food Prop. 11 (2008) 44-52.

[12] Aljane F., Toumi I., Ferchichi A., HPLC determination of sugars and atomic absorption analysis of mineral salts in fresh figs of Tunisian cultivars, Afr. J. Biotechnol. 6 (2007) 599-602.

[13] Colelli G., Aspetti fisiologici della maturazione e technologie postraccolta dei frutti di fico (Ficus carica L.), Riv. Frutticolt. 1 (1995) 71-77.
[14] Ozer B.K., Derici B., A research on the relationship between aflatoxin and ochratoxin a formation and plant nutrients, Acta Hortic. 480 (1998) 199-206.

[15] Humphry C.M., Clegg M.S., Keen C.L., Grivetti L.E., Food diversity and drought survival, The Hausa example, Int. J. Food Sci. Nutr. 44 (1993) 1-16.

[16] Anon., Official methods of analysis, Assoc. Off. Anal. Chem. (AOAC), 15th ed., Wash., DC, U.S.A., 1995.

[17] Kjeldahl J., Determination of protein nitrogen in food products, Encyc. Food Agric. 28 (1983) 757-765.

[18] Rangana S.C., Manual of analysis of fruit and vegetable products, Tata Mc Graw Hill Publ. Co. Ltd., New Delhi, India, 1979.

[19] Indrayan A.K., Sharm S., Durgapal D., Kumar N., Kumar M., Determination of nutritive value and analysis of mineral elements for some medicinally valued plants from Uttraranchal, Curr. Sci. 89 (2005) 1252-1255.

[20] Toth S.J., Prince A.L., Wallace A., Mikkenlsen D.S., Rapid quantitative determination of eight mineral elements in plant tissue: Systematic procedure involving use of a flame photometer, Soil Sci. 66 (1948) 459-466.

[21] Hussain I., Khan H., Investigation of heavy metals content in medicinal plant, Eclipta alba L., J. Chem. Soc. Pak. 32 (2010) 28-33.

[22] Sekine T., Sasakawa T., Morita S., Kimura T., Kuratom K., A laboratory manual for physiological studies of rice, Int. rice res. Inst. (Ed.), Manila, India, 1965.

[23] Omobuwajo T.O., Omobuwajo O.R., Sanni L.A., Physical properties of calabash nutmeg (Monodora mristica) seeds, J. Food Eng. 57 (2003) 375-381.

[24] Ozcan M.M, Haciseferogullari H., The strawberry (Abutus unedo L.) fruits: chemical composition, physical-properties and mineral contents, J. Food Eng. 78 (2007) 10221028.

[25] Demir F., Ozcan M., Chemical and technological properties of rose (Rosa canina L.) fruits grown wild in Turkey, J. Food Eng. 47 (2001) 333-336.

[26] Cemeroglu B., Acar J., Fruit and vegetable processing technology, Turk. Assoc. Food Technol. 6 (1986) 508

[27] Patel P.R., Gol N.B., Rao T.V.R., Physiochemical changes in sunberry (Physalis minima L.) fruit during growth and ripening, Fruits 66 (2011) 37-46. 
[28] PheBe D., YeiKheng T., Physicochemica characteristics of dabai (Canarium odontophyllum Miq.) fruit, Fruits 66 (2011) 47-52.

[29] Effiong G.S., Ibia T.O., Udofia U.S., Nutritive and energy values of some wild fruit spices in south eastern Nigeria, Electron. J. Environ. Agric. Food Chem. 8 (10) (2009) 917-923.

[30] Andola H.C., Rawal R.S., Bhatt I.D., Comparative studies on the nutritive and antinutritive properties of fruits in selected Berberis species of West Himalaya, India, Food Res. Int. 44 (2011) 2352-2356.

[31] Imran M., Talpur F.N., Jan M.S., Khan A., Khan I., Analysis of nutritional components of some wild edible plants, J. Chem. Soc. Pak. 29 (2007) 500-508.

[32] Macrae R., Robinson R.K., Sadler M.J., Encyclopaedia of food science, Food technol. Nutr. 5 (1993) 3126-3131.

[33] Brody T., Nutritional biochemistry, Acad. Press, San Diego, CA, U.S.A., 1994, pp. 555556.

[34] Lewis C.A., Green nature/human nature: The meaning of plants in our lives, Univ. Illinois Press, Urbana, Chicago, U.S.A., 1996.
[35] Akpanabiatu M.I., Bassey N.B., Udosen E.O., Eyong E.U., Evaluation of some minerals and toxicants in some Nigerian soup meals, J. Food Compos. Anal.11 (1998) 292297.

[36] Alessandra G., Robert H.C., The crucial role of metal ions in neurodegeneration: the basis for promising therapeutic strategy, $\mathrm{Br}$. J. Pharm. 146 (2005) 1041-1059.

[37] Mills D.F., Symposia from the XII International Congress on Nutrition, Prog. Clin. Biol. Res. 77 (1981) 165-171.

[38] Khan K.Y., Khan M.A., Niamat R., Munir M.F., Element content analysis of plants of genus Ficus using atomic absorption spectrometer, Afr. J. Pharm. Pharmacol. 5 (2011) 317-321.

[39] Obiajunwa E.I., Adebajo A.C., Omobuwajo O.R., Essential and trace element contents of some Nigerian medicinal plants, J. Radioanal. Nucl. Chem. 252 (2002) 473-476.

[40] Wildman R., Medeiros D., Advanced human nutrition, CRC Press, Boca Raton, Fla., U.S.A., 2000

\section{Evaluación de los nutrientes y de los recursos minerales de los frutos de higueras y moreras silvestres comestibles.}

Resumen - Introducción. Las plantas silvestres representan un regalo de la naturaleza para la humanidad. Teniendo en cuenta la creciente necesidad de identificar nuevas fuentes de bionutrición, ciertas especies poco utilizadas de higueras (Ficus carica L., F. palmata Forssk., F. racemosa L.) y de moreras (Morus alba L., M. nigra L, M. laevigata Wall.) de la familia de las Moraceae se evaluaron como frutos silvestres comestibles para estudiar su composición nutritiva y mineral, con el fin de priorizar su consumo entre las poblaciones autóctonas. Material y métodos. Se determinó, empleando métodos oficiales de la AOAC, la composición global de los frutos estudiados (humedad, cenizas, lípidos, proteínas, fibras y glúcidos). Se definió, mediante el empleo de un espectrofotómetro de absorción atómica, la concentración de diversos minerales (K, Ca, Mg et Na) y de oligo elementos ( $\mathrm{Fe}, \mathrm{Mn}$, Zn, Cu y Ni). Resultados. Nuestros resultados revelaron una gama de contenidos de humedad de 17,82-80,37 g.100 g g $^{-1}$ (peso fresco) para F. carica-M. laviegata; de proteínas, de $6,31-13,50 \mathrm{~g} \cdot 100 \mathrm{~g}^{-1}$ (peso seco) para $F$. glomerata- $M$. alba; de grasas brutas, de $1,02-2,71 \mathrm{~g} \cdot 100 \mathrm{~g}^{-1}$ para $F$. palmate $-F$. glomerata; de hidratos de carbono, de $69,47-75,58 \mathrm{~g} \cdot 100 \mathrm{~g}^{-1}$ para M. alba-M. nigra; de fibras, de 7.63$17,81 \mathrm{~g} \cdot 100 \mathrm{~g}^{-1}$ para M. laviegata-F. palmate, respectivamente. Se calculó un valor energético significativamente elevado para M. laviegata $\left(367,7 \mathrm{kcal} \cdot 100 \mathrm{~g}^{-1}\right)$. Asimismo en todas las especies estudiadas se encontraron cantidades nada despreciables de elementos esenciales. Los niveles más altos de $\mathrm{N}\left[(0,24 \pm 0,07) \mathrm{mg} \cdot \mathrm{g}^{-1}\right]$ y $\mathrm{Fe}\left[\left(1,43 \pm 0,42 \mathrm{mg} \cdot \mathrm{g}^{-1}\right]\right.$ se encontraron en M. laviegata; de Na $\left[\left(1,92 \pm 0,11 \mathrm{mg} \cdot \mathrm{g}^{-1}\right]\right.$ y Mg $\left[\left(6,92 \pm 0,37 \mathrm{mg} \cdot \mathrm{g}^{-1}\right]\right.$, en $F$. palmate; y K $[(17,21 \pm$ $0,03 \mathrm{mg} \cdot \mathrm{g}^{-1}$ ], en $F$. glomerata. Para todos los elementos nutricionales aparecieron variaciones significativas entre las especies estudiadas. Conclusión. Según nuestros resultados, los frutos de higueras y de moreras deberían recomendarse a escala de una producción comercial para la industria verde, con el fin de vencer las crisis alimentarias en cuanto a fuente potencial de alimentación cotidiana, particularmente los frutos de Morus laviegata y Ficus palmata, los cuales poseen ricas propiedades nutricionales y perfiles minerales.

Pakistán / Morus / Ficus / frutas / composición aproximada / contenido mineral 